\title{
Characterization of the physiological quality of soybean seeds produced in Santa Catarina State
}

\section{Caracterização da qualidade fisiológica de sementes de soja produzidas em Santa Catarina}

\author{
Vanderléia Mathias ${ }^{1}$; Cileide Maria Medeiros Coelho ${ }^{2 *}$; Cristhyane Garcia Araldi²; \\ Daniele Nerling 2 ; Paulo Tarcísio Domatos de Borba ${ }^{3}$; Virgílio Gavicho Uarrota ${ }^{4}$
}

\begin{abstract}
The soybean seeds produced in Santa Catarina have the potential for the application of new marketing strategies because they have superior quality over the minimum standards established by the Brazilian legislation. This potential was verified using time series analysis (TS). The main goal of this study was to characterize the physiological quality of soybean seeds produced in the State of Santa Catarina using data from the last five harvests in order to establish new commercialization strategies based on seed quality. Historical data for germination and vigor were obtained from the 2012/2013 to 2016/2017 harvests, with a total of 4606 lots studied. To validate the historical data, data from the 2016/2017 harvest were included. For this analysis, 100 lots of soybean seeds from the 2016/2017 harvest were collected, and laboratory tests for germination and vigor were performed. The results of the time series analysis showed that, on average, the germination rate ranged from 89 to $93 \%$, with all values being higher than the minimum required for commercialization by the Brazilian legislation. Vigor ranged on average from 82 to $90 \%$. Currently, there is no reference value for vigor in the Brazilian legislation for seed commercialization purposes. Of the total of lots evaluated, $1 \%, 2 \%, 21 \%$, and $76 \%$ of seeds presented germination $<70 \%, 70-80 \%, 80-90 \%$, and $>90 \%$, respectively, whereas $4 \%, 3 \%, 7 \%, 17 \%$, and $69 \%$ of the lots presented vigor $<70 \%, 70-75 \%, 75-80 \%, 80-85 \%$, and $>85 \%$, respectively. Considering that $76 \%$ of the lots presented germination $>90 \%$ and $69 \%$ of the lots had vigor $>85 \%$, the lots that presented these percentages were ranked, and $64 \%$ were determined to meet high quality standards. Taking into account the 100 sampled lots from the 2016/2017 harvest, 55\% presented germination $>90 \%$ and $58 \%$ had vigor $>85 \%$. In this harvest, $41 \%$ of the lots met the standards of at least $90 \%$ germination and $85 \%$ vigor according to the ranking methodology. This study concludes that due to the stability of climatic conditions, the State of Santa Catarina produces soybean seeds with physiological quality above the minimum standards, which allow the establishment of a minimum vigor standard of $85 \%$ for the commercialization of soybean seeds.
\end{abstract}

Key words: Germination. Glycine max. Time series. Vigor.

1 Doutora pela Universidade do Estado de Santa Catarina, Centro de Ciências Agroveterinárias, UDESC/CAV, Lages, SC, Brasil. E-mail: vanderleia.mathias@gmail.com

2 Profs., UDESC/CAV, Lages, SC, Brasil.E-mail: cileide.souza@udesc.br; cristhyane.araldi@udesc.br; danielenerling@gmail.com

3 Eng $^{\circ}$ Agr $^{\circ}$, Companhia Integrada de Desenvolvimento Agrícola de Santa Catarina, CIDASC, Lages, SC, Brasil. E-mail: ptdborba@gmail.com

4 Pesquisador, Pontifica Universidad Católica de Valparaiso, La Palma, Quillota, Chile. E-mail: uaceleste@yahoo.com.br

* Author for correspondence 


\section{Resumo}

As sementes de soja produzidas em Santa Catarina têm potencial para novas estratégias de comercialização, pois possuem qualidade superior aos padrões mínimos exigidos pela legislação. A comprovação deste potencial é possível através do uso de análise de séries temporais. Com isso, o objetivo deste estudo foi caracterizar a qualidade fisiológica de sementes de soja produzidas no estado de Santa Catarina nas últimas 5 safras, buscando estabelecer novas estratégias de comercialização com base na qualidade das sementes. Os resultados históricos dos percentuais de germinação e vigor de sementes de soja foram obtidos das safras 2012/2013 a 2016/2017, totalizando 4606 lotes. Para validação desses dados, na safra 2016/2017 foram coletadas 100 amostras de sementes de soja e conduzido o teste de germinação e vigor no laboratório de análise de sementes. Os dados do histórico foram submetidos à análise estatística usando séries temporais e regressão. Ao conjunto de dados foram incluídos os 100 lotes analisados na safra 2016/2017 e ranqueados em classes de germinação e vigor. O percentual de germinação e vigor dos lotes manteve-se superior a $90 \%$ e $87 \%$, respectivamente, com redução de $0,32 \%$ na germinação e $0,80 \%$ para vigor ao longo das cinco safras analisadas, evidenciando que há manutenção da qualidade das sementes ao longo das safras. A manutenção está atrelada à fatores climáticos favoráveis a produção e ao armazenamento de sementes de soja observados em Santa Catarina. Do total de lotes analisados (4606) nas cinco safras, 3.500 lotes (76\%) apresentaram germinação superior a 90\% e 3.178 lotes $(69 \%)$ vigor superior a 85\%. Dos 100 lotes analisados na safra 2016/2017, 55 apresentaram germinação acima de $90 \%$ e 58 vigor superior a $85 \%$. Os resultados obtidos na safra 2016/2017 validam a série histórica e comprovam a elevada qualidade fisiológica das sementes de soja produzidas em Santa Catarina. O estudo permite concluir que em função da estabilidade das condições climáticas o estado de Santa Catarina produz sementes de soja com qualidade fisiológica acima dos padrões mínimos, o que possibilita estabelecer um padrão mínimo de vigor de $85 \%$ para a comercialização de sementes de soja.

Palavras-chave: Germinação. Glycine max. Series temporais. Vigor.

\section{Introduction}

Soybean seed production can be affected by several edaphoclimatic factors. In Santa Catarina State (Brazil), $15 \%$ of the soybean production area is destined for seed production, representing 2006 production fields registered at the Ministry of Agriculture and Livestock that produce 312000 tons of seeds annually (Ministério da Agricultura, Pecuária e Abastecimento [MAPA], 2018).

The area destined for soybean production in the State of Santa Catarina during the 2017/2018 harvest was 678200 hectares, with a production of 2.3 million tons (Companhia Nacional de Abastecimento [CONAB], 2018). Of this area, approximately 92800 hectares were destined for seed production (MAPA, 2018). The state is responsible for the production of $16 \%$ of the national soybean seed market, commercializing $86 \%$ of its production to the states of Paraná, Rio Grande do Sul, São Paulo, and Mato Grosso do
Sul and to neighboring countries such as Argentina and Paraguay (Associação Brasileira de Sementes e Mudas [ABRASEM], 2018). The production of soybean seeds in Santa Catarina is concentrated in regions with an altitude greater than $700 \mathrm{~m}$ and latitudes above $24{ }^{\circ} \mathrm{S}$. These characteristics contribute to obtaining seeds of high physiological quality (França et al., 2016).

Seed physiological quality is characterized by its germination and vigor, which are determining characteristics in the initial establishment of the crop. Germination comprises an orderly sequence of metabolic events that result in the development of the embryo and the subsequent origination of the seedling (Marcos, 2015). From the point of view of seed technology, germination can be defined by seedling emergence under ideal sowing conditions (Marcos, 2015). Seeds with high vigor guarantee the development of normal and vigorous seedlings and enable a rapid and uniform emergence even 
in adverse climatic conditions (Corbineau, 2012; Di Girolamo, \& Barbanti, 2012). Germination is considered the most critical phase of plant development due to its high vulnerability to climatic stresses (Rajjou et al., 2012). Thus, the use of seeds with high physiological quality guarantees the uniformity of the emergence and the stability of crop yields (Egli, Hamman, \& Rucker, 2010).

High-quality seeds must meet a set of standards defined by the seed production sector and be supported by national and international regulations (Bishaw, Struik, \& Van Gastel, 2012). Soybean seeds marketed in the national territory must present minimum percentages of $99 \%$ purity and $80 \%$ germination, except for the basic seed category, whose minimum germination percentage is $75 \%$ (Instrução Normativa $n^{\circ} 45,2013$ ). Considering the vigor parameter, there is no minimum standard for commercialization as tests are not included in the rules for the analysis of domestically produced seeds. At the international level, accelerated aging tests are included in the rules for seed analysis of the International Seed Testing Association (ISTA) as an indicator of soybean seed vigor (Marcos, 2015).

The permanence of seed production companies in the competitive seed market requires the production of seeds with a quality superior to the minimum established by the legislation, ensuring the consumer a high vigor of seed lots. In this regard, the literature shows the potential of the State of Santa Catarina for the production of soybean seeds with a quality that exceeds the minimum standards. Some authors have observed $90-97 \%$ germination and $>70 \%$ vigor for different soybean cultivars produced in the state (Pereira, Coelho, Souza, Mantovani, \& Mathias, 2015a; Pereira, Coelho, Sobiecki, \& Souza, 2015b).

The verification of soybean seed production with qualities superior to the minimum standards is possible through time series analysis. The use of time series is used as a differential tool in the study of behaviors and tendencies. Temporal series can be defined as sequences of quantitative data related to specific moments and studied according to their distribution over time (Wiener, 1966). This feature has been used in different areas of science to extract information and characteristics from historical data. From this information, it is possible to infer the continuity of behaviors and tendencies, such as the percentage of germination and vigor for subsequent harvests. Therefore, the main objective of this research was to characterize the physiological quality of soybean seeds produced in the State of Santa Catarina in five harvests in order to establish subsidies for new marketing strategies based on seed quality.

\section{Materials and Methods}

The study was developed by the Seed Analysis Laboratory of the Agroveterinary Science Center of the University of Santa Catarina State (CAV/ UDESC). Climatic conditions and data related to the production and quality of soybean seeds in the State of Santa Catarina were analyzed considering the harvests from 2012/2013 to 2016/2017.

Information on physiological quality was provided by the seed companies operating in the region. This information was taken from the Seed Analysis Bulletins (BAS) and results newsletters (IR) of internal quality control. The data refer to the percentage of germination obtained in the germination test, recommended by the rules for seed analysis (MAPA, 2009) and the vigor evaluated by the accelerated aging test $\left(41^{\circ} \mathrm{C}\right.$ for 48 hours) according to the methodology described by Marcos, Kikuti and Lima (2009).

Taking into account the datasets provided by the seed companies, 4606 seed lots were evaluated, of which $674,959,1010,972$, and 991 corresponded to the $2012 / 2013,2013 / 2014,2014 / 2015,2015 / 2016$, and 2016/2017 harvests, respectively. In order to validate the results of seed physiological quality provided by the companies, 100 samples of seed lots were collected from the 2016/2017 harvest and the physiological evaluation was carried out 
through the germination and accelerated aging tests. The number of samples (n) collected was defined based on the average germination $(\mu)$ of the 4606 lots, following the equation:

$$
\mathrm{n}=\left(\frac{1,96}{0,05}\right)^{2} \cdot \mu \quad \cdot(1-\mu)
$$

The sampling of representative samples of the plots was carried out during the months of August and September 2017, considered the pre-harvest period. The sampling was performed randomly, directly in the cooperatives and seed producers of the state. Based on the edaphoclimatic characteristics, the production of soybean seeds in the state is divided into four regions, West, Midwest, North Plateau, and Serrano Plateau that represent 35.9\%, 51.7\%, $6.3 \%$, and $6.1 \%$ of the state production, respectively (Figure 1). The number of batches collected varied according to the percentage of production in each region, so that $60,30,5$, and 5 lots were collected from the Midwest, West, North Plateau, and Serrano Plateau regions, respectively.

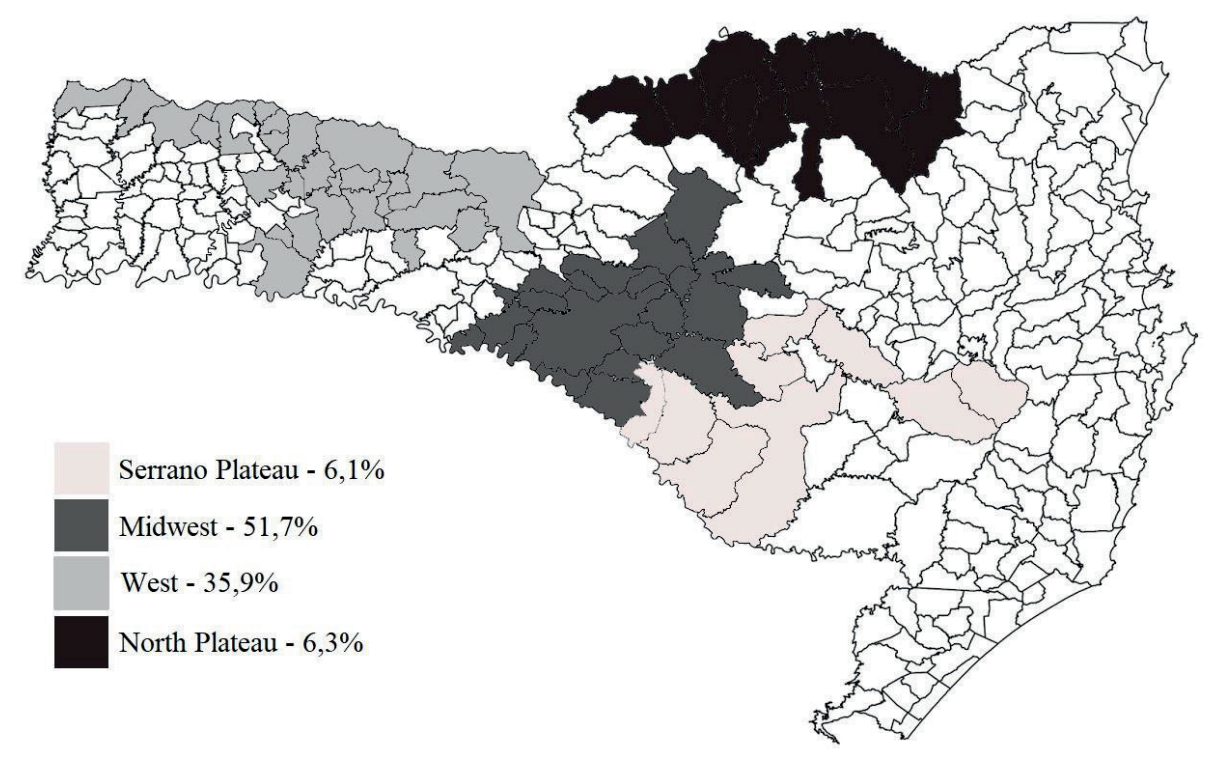

Figure 1. Soybean Seed production regions in Santa Catarina State.

In the sampling procedure, the number of simple samples collected depended on the size of seed lots, following the recommendations of the rules for seed analysis. Thus, in batches of 3001-20000 kg, one sample was collected for every $500 \mathrm{~kg}$, while in lots of more than $20000 \mathrm{~kg}$, one sample was extracted for every $700 \mathrm{~kg}$. From the simple samples, composite samples were obtained, and they were reduced, originating mean samples (1000 g;) (Ministério da Agricultura, Pecuária e Abastecimento [MAPA] 2009). In the laboratory, each mean sample was homogenized and reduced, obtaining a working sample (500 g), which was subdivided into four sub-samples. The germination and accelerated aging tests were performed on the sub-samples.

The germination test was carried out with 400 seeds per lot, arranged in eight rolls of 50 seeds, using germitest paper as substrate and placed in a germinator with a temperature of $25 \pm 2{ }^{\circ} \mathrm{C}$. The first evaluation was performed on the fifth day after sowing and the second evaluation was carried out the eighth day. The results were expressed as a percentage of normal seedlings (MAPA, 2009) and standard deviation (SD). 
The accelerated aging test was conducted for vigor determination, using 400 seeds per lot, distributed in a single layer on a steel screen and placed inside Gerbox-type plastic boxes containing $40 \mathrm{~mL}$ of distilled water, with a distance between the water level and the seeds of approximately $2 \mathrm{~cm}$. The boxes were closed and taken to an aging chamber, regulated at a temperature of $41{ }^{\circ} \mathrm{C}$ for 48 hours (Marcos et al., 2009). Then, the germination test was performed with the first evaluation performed on the fifth day and the second evaluation on the eighth day after sowing. The results were expressed as the percentage of normal seedlings (MAPA, 2009).

The percentages of germination and vigor of 4606 lots were subjected to statistical analysis using time series and regression. The data set included the 100 batches analyzed in the 2016/2017 crop and ranked in germination and vigor classes with the aid of the R Software (R Core Team, 2016).
In order to complement this information, we conducted surveys of soybean seed production in the State of Santa Catarina, accounting for the number of fields, area (hectares), and seed production (tons). Data were obtained from the Surveillance Management System (MAPA, 2018).

The climatic conditions that occurred during the study period were considered during the interval from October to April. Average temperature $\left({ }^{\circ} \mathrm{C}\right)$ and rainfall $(\mathrm{mm})$ data were obtained from the Instituto Nacional de Meteorologia [INMET] (2018), from meteorological stations located in the municipalities of Chapecó, Campos Novos, and Lages, which belong to the main seed-producing regions of the state (Figures 1 and 2). Climatic data were subjected to statistical analysis using time series with the R Software (R Core Team, 2016).
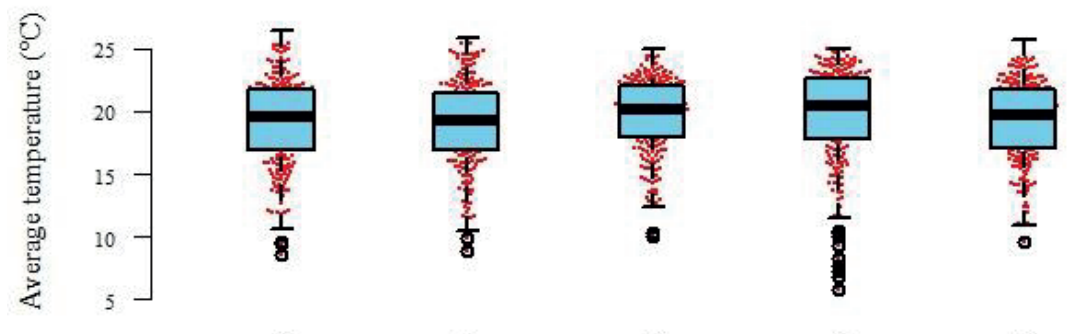

ำ

$\stackrel{m}{\stackrel{ก}{ก}}$

ㅎํㄴ

กิ

ลัก

Harvests
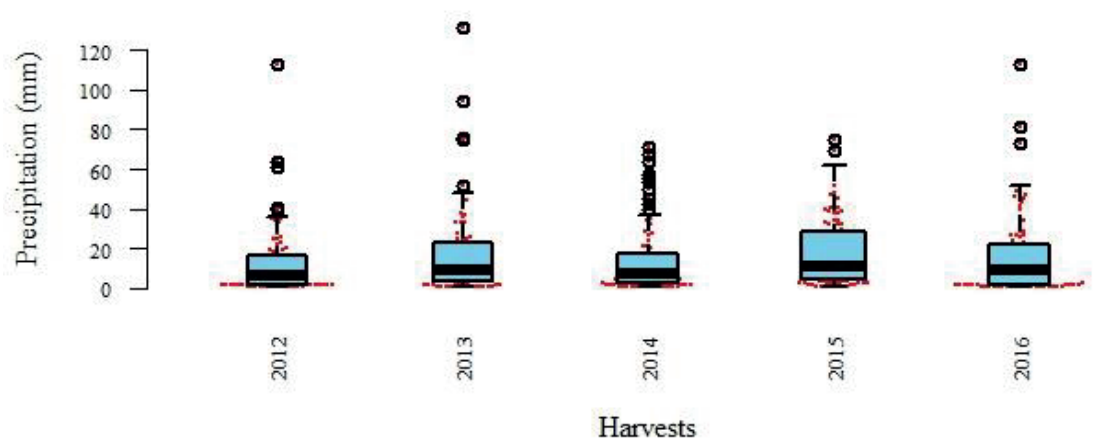

Figure 2. Average temperature $\left({ }^{\circ} \mathrm{C}\right)$ and precipitation $(\mathrm{mm})$ during the harvests from box plot of average 2012/2013 to 2016/2017. 


\section{Results and Discussion}

The time series analysis showed that the average germination percentage was 92\% (Figure 3). Of the total of batches evaluated between the harvests from 2012/2013 to $2016 / 2017,97 \%$ were in the range of $89-93 \%$ germination (Figure 3 ). In the $2012 / 2013$ harvest, it was observed that the batches presented, on average, the best performance, with $93 \%( \pm 5)$ germination, followed by those of the
$2013 / 2014$ harvest, with $92 \%$ ( \pm 3 ) germination. For the remaining harvests, the germination percentage was similar among them, with a mean of $91 \%$ $( \pm 5)$ germination (Figure $4 a)$. The germination percentages observed in the temporal analysis are higher than the minimum required by the Brazilian legislation for the commercialization of soybean seeds (Instrução Normativa $n^{\circ} 45,2013$ ).

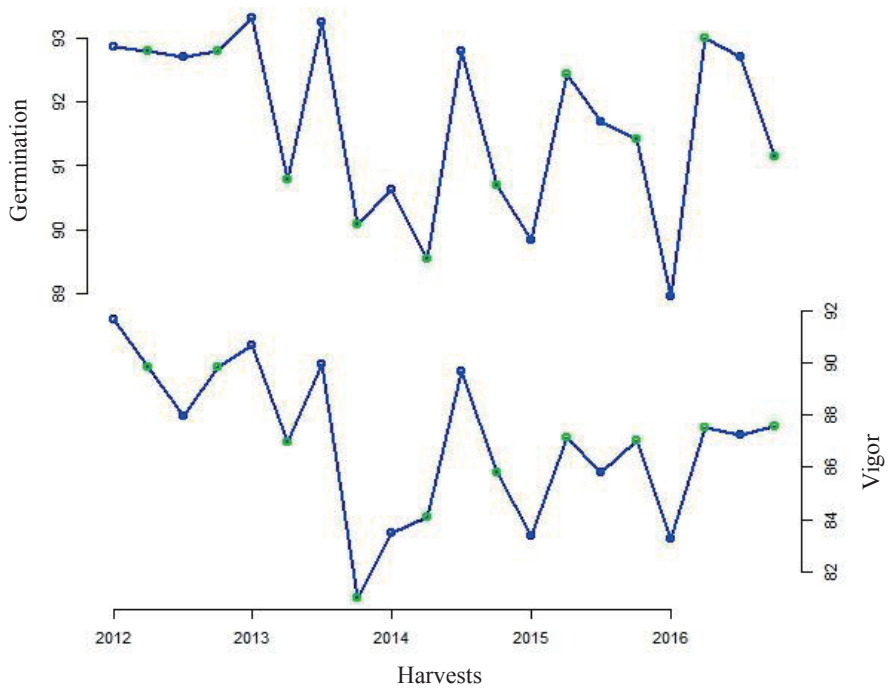

Figure 3. Germination and vigor of the soybean seeds lots produced in the State of Santa Catarina (SC) during the harvests $2012 / 2013$ to $2016 / 2017$.
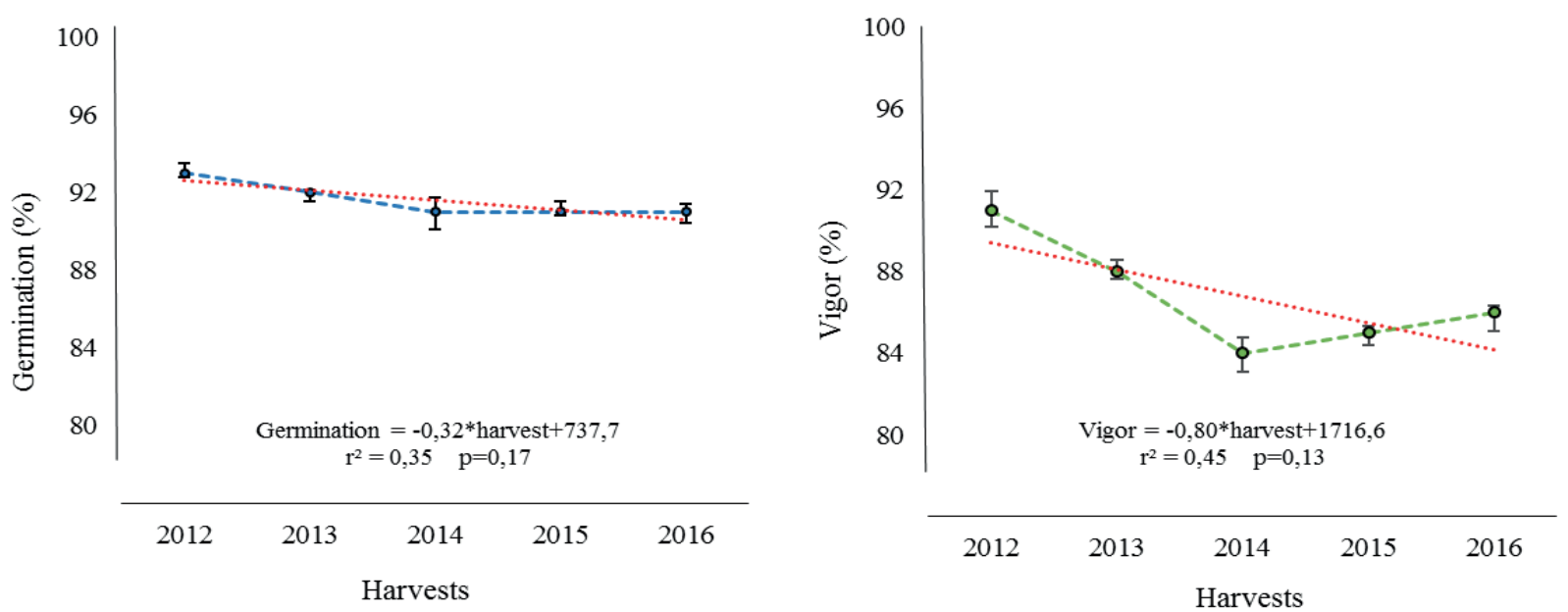

Figure 4. Regression curves of germination and vigor of soyban seeds during the harvests studied. Bars indicates $95 \%$ confidence intervals (IC). 
The average percentage of seed vigor of the five harvests was $87 \%$ (Figure 3). It was also found that $86 \%$ of the batches presented vigor in the range between 82 and 90\% (Figure 3). In the 2012/2013 harvest, it was observed that the plots had an average of $92 \%( \pm 6)$ vigor. For the subsequent harvests $(2013 / 2014,2014 / 2015,2015 / 2016$, and $2016 / 2017)$, the Vigor was $88 \%( \pm 6), 84 \%( \pm 9)$, $85 \%( \pm 10)$, and $86 \%( \pm 6)$, respectively (Figure $4 \mathrm{~b})$. Despite the high vigor observed, there are no standards of vigor legally established by the Ministry of Agriculture, Livestock, and Food Supply for the commercialization of seeds in Brazil. However, the reference values are established by the seed companies themselves, which use this characteristic as a marketing strategy, with the aim of adding value in the commercialization of seeds.

The regression analysis indicates a reduction of $0.32 \%$ and $0.80 \%$ in the germination and vigor, respectively, during the five harvests analyzed (Figures $4 \mathrm{a}$ and $4 \mathrm{~b}$ ). Based on these results, it is possible to suggest that the State of Santa Catarina presents good potential for the production of seeds with higher physiological quality.

The analysis of the climatic conditions of the last five harvests indicates that there are no statistical differences in the average air temperature and rainfall, which demonstrates the stability of climatic conditions in the State of Santa Catarina (Figure 2 ). Another aspect that favors the production of soybean seeds in Santa Catarina is related to the average temperature and relative humidity during the desiccation phase of seeds, which comprises the months of March, April, and May. During this period, the average air temperature varied over a range extending from 15 to $20{ }^{\circ} \mathrm{C}$ and the relative humidity ranged from 78 to $86 \%$ (INMET,
2018). These conditions, in addition to favoring the production of high-quality seeds, minimize the effects of the deterioration process. The speed of the deterioration process is determined mainly by the interaction between cultivars and climatic conditions, such as high temperatures and higher relative humidity of the air (Jyoti \& Malik, 2013; Khan et al., 2011).

In order to deeply understand the behavior of physiological parameters, germination and vigor classes were established (tables 1 and 2). Among the plots evaluated, $1 \%, 2 \%, 21 \%$, and $76 \%$ presented $<70 \%, 70-80 \%, 80-90 \%$, and $>90 \%$ germination, respectively (Table 1 ). In terms of vigor, $4 \%, 3 \%$, $7 \%, 17 \%$, and $69 \%$ of the batches exhibited $<70 \%$, $70-75 \%, 75-80 \%, 80-85 \%,>85 \%$ vigor (Table 2 ). Considering the results of the 100 lots evaluated in the 2016/2017 harvest, 55\% presented $>90 \%$ germination and $58 \%$ exhibited $>85 \%$ vigor.

Assuming that $76 \%$ of the batches presented $>$ $90 \%$ germination (Table 1) and $69 \%$ of the lots had $>85 \%$ vigor (Table 2 ), the batches that presented these percentages were ranked concomitantly. Thus, among the lots that presented $\geq 90 \%$ germination, $64 \%$ also presented $>85 \%$ vigor, representing high-quality lots. These results demonstrate the potential of Santa Catarina State for the production of soybean seeds, with germination patterns above the minimum required for commercialization (Instrução Normativa $n^{\circ} 45,2013$ ) and allowing the establishment of a minimum standard of $85 \%$ vigor. Following these seed quality criteria, $41 \%$ meet these minimum standards. In addition, the results obtained in the 2016/2017 harvest validate the results and prove the high physiological quality of soybean seeds produced in the State of Santa Catarina. 
Table 1

Lot classification according to germination rate for each season of harvest. 16/17* means results of the 100 lots analysis

\begin{tabular}{|c|c|c|c|c|c|c|c|c|c|}
\hline \multicolumn{10}{|c|}{ Germination } \\
\hline \multirow[b]{2}{*}{ Harvest } & \multirow{2}{*}{$\frac{\text { Class I }}{[0 \text { a } 70]}$} & & \multirow{2}{*}{$\frac{\text { Class II }}{[70 \text { a } 80]}$} & \multirow[b]{2}{*}{$(\%)$} & \multirow{2}{*}{$\begin{array}{c}\text { Class III } \\
\text { [80 a 90] }\end{array}$} & \multicolumn{3}{|c|}{ Class IV } & \multirow{2}{*}{ Total } \\
\hline & & $(\%)$ & & & & $(\%)$ & [90 a 100] & $(\%)$ & \\
\hline $12 / 13$ & 3 & 1 & 7 & 1 & 90 & 13 & 574 & 85 & 674 \\
\hline $13 / 14$ & 0 & 0 & 2 & 0 & 165 & 17 & 792 & 83 & 959 \\
\hline $14 / 15$ & 6 & 0 & 26 & 3 & 252 & 25 & 726 & 72 & 1010 \\
\hline $15 / 16$ & 12 & 1 & 32 & 3 & 196 & 20 & 732 & 76 & 972 \\
\hline $16 / 17$ & 6 & 1 & 26 & 3 & 263 & 26 & 696 & 70 & 991 \\
\hline $16 / 17^{*}$ & 0 & 0 & 0 & 0 & 45 & 45 & 55 & 55 & 100 \\
\hline Total & 27 & 1 & 93 & 2 & 1011 & 21 & 3575 & 76 & 4706 \\
\hline
\end{tabular}

Table 2

Lot classification according to vigor for each season of harvest. 16/17* means results of the 100 lots analysis

\begin{tabular}{cccccccccccc}
\hline \multicolumn{10}{c}{ Vigor } \\
\hline & Class I & & Class II & & Class III & & Class IV & \multicolumn{3}{c}{ Class V } & Total \\
\hline Harvest & {$[0$ a 70] } & $(\%)$ & {$[70$ a 75] } & $(\%)$ & {$[75$ a 80$]$} & $(\%)$ & {$[80$ a 85] } & $(\%)$ & {$[85$ a 100] } & $(\%)$ & \\
\hline $12 / 14$ & 4 & 1 & 5 & 1 & 16 & 2 & 42 & 6 & 607 & 90 & 674 \\
$13 / 14$ & 3 & 0 & 30 & 3 & 74 & 8 & 135 & 14 & 717 & 75 & 959 \\
$14 / 15$ & 73 & 7 & 50 & 5 & 74 & 7 & 177 & 18 & 636 & 63 & 1010 \\
$15 / 16$ & 63 & 6 & 36 & 4 & 73 & 8 & 167 & 17 & 633 & 65 & 972 \\
$16 / 17$ & 21 & 2 & 34 & 3 & 95 & 10 & 235 & 24 & 606 & 61 & 991 \\
$16 / 17^{*}$ & 4 & 4 & 0 & 0 & 2 & 2 & 36 & 36 & 58 & 58 & 100 \\
\hline Total & 168 & 4 & 155 & 3 & 334 & 7 & 792 & 17 & 3257 & 69 & 4706 \\
\hline
\end{tabular}

Since only $7 \%$ of the batches presented $\leq 74 \%$ vigor, it would be possible to establish a minimum standard for the vigor criterion in the Brazilian soybean seed legislation. The need to include vigor patterns for the commercialization of seeds is strengthened by the fact that a large proportion of producers and users of soybean seeds already request vigor analyses for seed valuation purposes and sowing calculations.

The high-quality of soybean seeds produced in the State of Santa Catarina was verified by overlapping the confidence intervals of historical data. In studies carried out with the objective of evaluating the physiological quality of soybean seeds produced by companies from different regions of the state, values similar to those found in the present study were observed. In the 2013/2014 crop, Frandoloso, Meneghello, André, Deuner and Menegaz (2015), evaluating the physiological quality of 24 batches produced in the municipalities of Xanxerê, Abelardo Luz, Campos Novos and Canoinhas, obtained a mean of $88 \%$ germination and $85 \%$ vigor.

During the 2014/2015 and 2015/2016 harvests, studies were carried out with the objective of determining the physiological quality of soybean seeds of lots collected from nine Brazilian states. In 
the State of Santa Catarina, 20 lots collected from the $2014 / 15$ harvest presented average values of $88 \%$ germination, $90 \%$ viability, and $80 \%$ vigor. These values are similar to those obtained in Mato Grosso, and inferior to those verified in Mato Grosso do Sul, Minas Gerais, and Goiás (França, 2016).

In the 2015/2016 harvest, the evaluation of 41 lots in the State of Santa Catarina showed means of $89 \%$ germination, $89 \%$ viability, and $80 \%$ vigor (França, Krzyzanowski, \& Pádua, 2017). When comparing the quality of soybean seeds produced in the Southern region of Brazil, it is observed that the average germination values obtained for the State of Santa Catarina are higher than those observed in the State of Paraná (87\%) and equal to those of Rio Grande do Sul (89\%). Regarding vigor, the average value of the State of Santa Catarina is higher than that of Paraná (76\%) and similar to that observed in Rio Grande do Sul (França et al., 2017). These results demonstrate the potential of the southern region of Brazil for the production of high-quality soybean seeds and are consistent with the results of the 4,706 lots presented in the present study for the State of Santa Catarina.

According to the climatic atlas proposed by Wrege et al. (2012), the regions of Santa Catarina suitable for the production of soybean seeds are located between latitudes from $26^{\circ} 17^{\prime} \mathrm{S}$ to $27^{\circ}$ $81^{\prime} \mathrm{S}$, longitudes of $49^{\circ} 80^{\prime} \mathrm{W}$ to $52^{\circ} 61^{\prime} \mathrm{W}$, and altitudes from 679 to $946 \mathrm{~m}$. The relative maturity groups (GMR) of the cultivars indicated for each region are established based on latitude and altitude (Alliprandini et al., 2009; Cavassim et al., 2013). In this context, it was found that in the 2016/2017 harvest, the state produced commercially seeds of cultivars that present GMR between 4.8 and 7.3 (MAPA, 2018). Moreover, during the 2011/2012 and 2012/2013 harvests, Carvalho, Uarrota, Souza and Coelho (2017) evaluated the behavior of 16 soybean cultivars with GMR between 4.7 and 6.7 in the municipality of Campos Novos. They found that seed quality ranged from 86 to $94 \%$ germination and
76 to $92 \%$ vigor when considering the cultivars ND 4725 RG (GMR 4.7) and BMX potency RR (GMR 6.7). These results corroborate the potential of the Midwestern region of the State of Santa Catarina for the production of high-quality seeds independently of the maturation group.

In addition to the climatic conditions that favor the production of seeds of high physiological quality, during the storage of seeds from June to September, the low average air temperatures $\left(<25^{\circ} \mathrm{C}\right)$ and relative humidity $(<70 \%)$ in the State of Santa Catarina favor the maintenance of vigor. According to França et al. (2016), the ideal conditions for the storage of soybean seeds are temperatures and humidity lower than $25{ }^{\circ} \mathrm{C}$ and $70 \%$, which ensure that the stored seeds remain with humidity around $12 \%$.

Based on the analysis of temporal series of climatic characteristics, stable conditions that allowed the production of seeds with high physiological quality were observed in all the evaluated harvests. Regardless of the harvest, the average germination was higher than $90 \%$ and vigor was close to $85 \%$. These results provide a scientific basis for the recognition of the State of Santa Catarina as a producer of soybean seeds of high physiological quality. The implementation of a Vigor + quality seal would allow the identification of soybean seed lots with minimum $90 \%$ germination and $85 \%$ vigor.

The commercialization of lots with quality above the standards assures the valorization of seeds. Furthermore, the use of high-quality seeds favors the establishment of the stand, with a rapid and uniform emergence and a higher production of the dry mass of seedlings (Abati, Brzezinski, Zucareli, Werner, \& Henning, 2017; Egli \& Rucker, 2012). Given the benefits of using high-quality seeds, the identification of batches with these characteristics is necessary to encourage producers to recommend the production of high-quality seeds. 


\section{Conclusions}

The State of Santa Catarina produces soybean seeds with physiological quality above the minimum germination patterns. The present study allows to establish a minimum vigor standard of $85 \%$ for the commercialization of soybean seeds. The high physiological quality observed throughout the harvests is mainly related to the climatic stability of the State of Santa Catarina.

\section{Acknowledgments}

The authors would like to thank the financial support of FAPESC to Mathias, V. and TR653PAP/ UDESC/FAPESC- project and the cooperatives for providing historical datasets and their facilities for sampling during the 2016/2017 harvest. The corresponding author (Coelho, C.M.M) thanks Conselho Nacional de Desenvolvimento Científico e Tecnológico $(\mathrm{CNPq})$ for productivity scholarship. Uarrota,V thanks the CONICYT-FONDECYT (Chile), project 3190055, for funding. This article is part of Mathias, $\mathrm{V}$ doctorate degree.

\section{References}

Abati, J., Brzezinski, C., Zucareli, C., Werner, F., \& Henning, F. (2017). Seed vigor and amount of soybean straw on seedling emergence and productive performance of wheat. Semina: Ciências Agrárias, 38(4), 2179-2186. doi: 10.5433/1679-0359.2017v38 n4p2179

Alliprandini, L. F., Abatti, C., Bertagnolli, P. F., Cavassim, J. E., Gabe, H. L., Kurek, A.,... Steckling, C. (2009). Understanding soybean maturity groups in brazil: environment, cultivar classification, and stability. Crop Science, 49(3), 801-808. Retrieved from https:/www.embrapa. br/busca-de-publicacoes/-/ publicacao/852648/understanding-soybeanmaturity-groups-in-brazil-environment-cultivarclassification-and-stability

Associação Brasileira de Sementes e Mudas. Estatísticas. Brasília: ABRASEM. Retrieved from: http://www. abrasem.com.br/estatisticas/

Bishaw, Z., Struik, P., \& Van Gastel, A. (2012). Farmers' seed sources and seed quality: 1. physical and physiological quality. Journal of Crop Improvement, 26(5), 655-692. doi: 10.1080/15427528.2012.670695

Carvalho, C. F., Uarrota, V. G., Souza, C. A., \& Coelho, C. M. M. (2017). Physiological quality of soybean seed cultivars (Glycine max (L.) Merr.) with different maturity groups. Research Journal of Seed Science, 10(2), 59-72. doi: 10.3923/rjss.2017.59.72

Cavassim, J., Bespalhok, J., Fo , Alliprandini, L., Oliveira, R. A., Daros, E., \& Guerra, E. P. (2013). Stability of soybean genotypes and their classification into relative maturity groups in Brazil. American Journal of Plant Sciences, 4(11), 2060-2069. doi: 10.4236/ ajps.2013.411258

Companhia Nacional de Abastecimento. (2018). Acompanhamento da safra brasileira de grãos safra 2017/18 (Vol. 5, n. 12, pp. 1-148). Brasília: CONAB. Recuperado de https://www.conab.gov.br/ info-agro/safras/graos

Corbineau, F. (2012). Markers of seed quality: from present to future. Seed Science Research, 22(Suppl. 1), S61-S68. doi: 10.1017/S0960258511000419

Di Girolamo, G., \& Barbanti, L. (2012). Treatment conditions and biochemical processes influencing seed priming effectiveness. Italian Journal of Agronomy, 7(2), 178-188. doi: 10.4081/ija.2012.e25

Egli, D. B, \& Rucker, M. (2012). Seed Vigor and the uniformity of emergence of corn seedlings. Crop Science, 52(6), 2774-2782. doi: 10.2135/ cropsci2012.01.0064

Egli, D. B., Hamman, B., \& Rucker, M. (2010). Seed vigor and uniformity of seedling emergence in soybean. Seed Technology Journal, 32(2), 87-95. Retrieved from https:/www.jstor. org/ stable/23433600?seq=1\#page_scan_tab_contents

França, J. B., Neto, Krzyzanowski, F. C., \& Pádua, G. P. (2017). Características fisiológicas da semente: vigor, viabilidade, germinação, danos mecânicos tetrazólio, deterioração por umidade tetrazólio, dano por percevejo tetrazólio e sementes verdes. In A. A. Henning, F. A. Henning, F. C. Krzyzanowski, G. P. Pádua, I. Lorini, J. B. França-Neto, J. M. G. Mandarino, M. A. Oliveira, M. H. Hirakuri, R. S. Leite, V. T. Benassi. Qualidade de sementes e grãos comerciais de soja no Brasil - safra 2015/16. (Seção I, pp. 35-61). Londrina: Embrapa Soja.

França, J. B., Neto, Krzyzanowski, F. C., Henning, A. A., Pádua, G. P., Lorini, I. \& Henning, F. A. (2016). Tecnologia da produção de semente de soja de alta qualidade. Londrina: Embrapa Soja. 
França, J. B., Neto. (2016). Características fisiológicas da semente: germinação, vigor, viabilidade, danos mecânicos tetrazólio, deterioração por umidade tetrazólio e dano por percevejo tetrazólio. In A. A. Henning, D. S. Corrêa, F. A. Henning, F. C. Krzyzanowski, G. P. Pádua, I. Lorini, J. B. FrançaNeto, J. M. G. Mandarino, M. A. Oliveira, M. H. Hirakuri, R. S. Leite, V. P. Scagion, V. T. Benassi. Qualidade de sementes e grãos comerciais de soja no Brasil - safra 2014/15. (Seção I, pp. 31-47). Londrina: Embrapa Soja.

Frandoloso, V., Meneghello, G. E., André, M. A., Deuner, C., \& Menegaz, W. (2015). Physiological quality of soybean seeds produced in four edaphoclimatic regions of Santa Catarina. Journal of Seed Science, 37(3), 226-233. doi: 10.1590/ 2317$1545 \mathrm{v} 37 \mathrm{n} 3150086$

Instituto Nacional de Meteorologia. (2018). Estações convencionais. Brasília: INMET. Recuperado de http://www.inmet.gov.br/sim/sonabra/dspDados Codigo.php?ODM4ODM.

Instrução Normativa $n^{\circ} 45$, de 17 de setembro de 2013. Dispõe sobre padrões de produção e a comercialização de sementes de grandes culturas. Recuperado de http:/www.agricultura.gov.br/ assuntos/insumos-agropecuarios/insumos-agricolas/ sementes-e-mudas/publicacoes-sementes-e-mudas/ copy_of_INN45de17desetembrode2013.pdf

Jyoti, \& Malik, C. P. (2013). Seed deterioration: a review. International Journal of Life Sciences Biotchenology and Pharma Reserch, 2(3), 374-385. Retrieved from: https://pdfs.semanticscholar.org/2fe3/ e 5 d 95 cc525690b9d03776c20041 caa4d 1 a 06 . pdf?_ga=2.266755722.501202613.15716108261897049009.1571610826

Khan, A. Z., Shah, P., Khan, H., Nigar, S., Perveen, S., Shah, M. K.,... Zubair, M. (2011). Seed quality and vigor of soybean cultivars as influenced by canopy temperature. Pakistan Journal of Botany, 43(1), 643648. Retrieved from https://www.researchgate.net/ publication/257136696_Seed_Quality_and_Vigor_ of_Soybean_Cultivars_as_Influenced_by_Canopy_ Temperature

Marcos, J., F', Kikuti, A. L. P., \& Lima, L. B. (2009). Métodos para avaliação do vigor de sementes de soja, incluindo a análise computadorizada de imagens. Revista Brasileira de Sementes, 31(1), 102-112. doi: 10.1590/S0101-31222009000100012
Marcos, J., Fo . (2015). Seed vigor testing: an overview of the past, present and future perspective. Scientia Agricola, 72(4), 363-374 doi: 10.1590/0103-90162015-0007

Ministério da Agricultura, Pecuária e Abastecimento. (2009). Regras para análise de sementes. Brasília: MAPA/ACS. Recuperado de http://www.agricultura. gov.br/assuntos/laboratorios/ arquivos-publicacoeslaboratorio/regras-para-analise-de-sementes.pdf/ view

Ministério da Agricultura, Pecuária e Abastecimento. Sistema da Gestão da Fiscalização. (2018). Controle da produção de sementes e mudas - Indicadores. Brasília: MAPA. Recuperado de http://indicadores. agricultura.gov.br/sigefsementes/index.htm

Pereira, T., Coelho, C. M. M., Sobiecki, M., \& Souza, C. A. (2015b). Physiological quality of soybean seeds depending on the preharvest desiccation. Planta Daninha, 33(3), 441-450. doi: 10.1590/S010083582015000300007

Pereira, T., Coelho, C. M. M., Souza, C. A., Mantovani. A., \& Mathias, V. (2015a). Dessecação química para antecipação de colheita em cultivares de soja. Semina: Ciências Agrárias, 36(4), 2383-2394. doi: 10. 5433/1679-0359.2015v36n4p2383

R Core Team. (2016). $R$ A language and environment for statistical computing (Version 3.1-103). Vienna: $R$ Foundation for Statistical Computing. Retrieved from https://www.R-project.org/

Rajjou, L., Duval, M., Gallardo, K., Catusse, J., Bally, J., Job, C., \& Job, D. (2012). Seed germination and vigor. Annual Review of Plant Biology, 63(1), 507533. doi: 10.1146/annurev-arplant-042811-1055 50

Wiener, N. (1966). Extrapolation, interpolation and smoothing of stationary time series. Cambridge: MIT Press.

Wrege, M. S., Steinmetz, S. S., Reisser, C., Jr., Almeida, I. R., Garrastazu, M. C., Herter, F. G.,... MALUF J. R. T. (2012). Atlas climático da Região Sul do Brasil: Estados do Paraná, Santa Catarina e Rio Grande do Sul. (2a ed.) Brasília: Embrapa Clima Temperado. Recuperado de https://www.embrapa.br/busca-depublicacoes/-/publicacao/1045852/atlas-climaticoda-regiao-sul-do-brasil-estados-do-parana-santacatarina-e-rio-grande-do-sul 
